\title{
Strategi Pembelajaran Bahasa dan Sastra Indonesia di Sekolah Dasar: Peran Guru dalam Menyikapi Kurikulum Tingkat Satuan Pendidikan ${ }^{1}$
}

\author{
Kushartanti
}

\begin{abstract}
ABSTR ACT Teaching Indonesian in formal schools today is regarded as a challenge by many Indonesian teachers. In a country like Indonesia, in which language situation is very complex due to many languages and dialects (and also the fast-growing English usage in big cities), this phenomenon can be understood. Since the country's independence, there have been several curricula - one of them is Kurikulum Berbasis Kompetensi (competence-based curriculum), the newest being Kurikulum Tingkat Satuan Pendidikan (Unit Level of Education-Based Curriculum). The latter seems to be regarded as the most ideal curriculum, because it can be adjusted to the regions' policy. The problems are that there are still Ujian Nasional (national examination) and that the 'readability' of the curriculum is still a big question for many teachers. This paper is focused on the elementary school teacher's strategies on applying the curriculum. This paper also discusses the curriculum, some principles on language learning, and the emergence of literary matters.

KEYWORDS competence based curriculum, unit level of education based curriculum, national examination, school teacher.
\end{abstract}

Indonesia adalah negara diglosik, yang memiliki bahasa nonstandar yang dipakai dalam situasi nonformal, dan bahasa standar yang dipakai dalam situasi formal. Bentuk bahasa nonstandar di Indonesia beragam. Ada bahasa daerah (yang beberapa di antaranya bahkan menjadi bahasa standar di daerahdaerah tertentu, seperti bahasa Jawa, bahasa Sunda, atau bahasa Makasar) yang dipakai oleh kelompok sosial tertentu, dan ada bahasa Indonesia nonstandar yang dipengaruhi oleh bahasa Jakarta, yang dipakai di kota-kota besar seperti Jakarta, Bandung, dan Medan.

Situasi diglosik ini bukanlah sesuatu yang aneh bagi anak-anak Indonesia.

1 Tulisan ini telah disampaikan pada Seminar Kurikulum Tingkat Satuan Pendidikan di FIB
UI, tanggal 22-23 Januari 2007 dan telah disesuaikan untuk kebutuhan Jurnal Wacana FIB UI. 
Pada umumnya mereka memperoleh bahasa nonstandar sebagai bahasa pertama, kemudian belajar bahasa standar di sekolah. Dewasa ini, banyak pula orang tua di kota besar yang menginginkan anak mereka untuk menguasai bahasa asing, terutama Inggris dan Mandarin. Karena itu, ada pula anak-anak yang menguasai kedua bahasa itu sebagai bahasa pertama.

Dapat dikatakan bahwa bahasa Indonesia adalah bahasa kedua bagi sebagian besar anak di Indonesia. Bahasa Indonesia secara formal mulai dipelajari ketika mereka duduk di bangku sekolah dasar. Di sekolah, pembelajaran bahasa Indonesia diarahkan untuk meningkatkan kemampuan mereka untuk berkomunikasi dalam bahasa Indonesia dengan baik dan benar, secara lisan dan tertulis, dan untuk menumbuhkan apresiasi terhadap hasil karya kesusastraan Indonesia.

Bagi guru, pembelajaran bahasa Indonesia merupakan suatu tantangan tersendiri, mengingat bahwa bahasa ini-bagi sebagian besar sekolah di Indonesia - merupakan bahasa pengantar yang dipakai untuk menyampaikan materi pelajaran yang lain. Pembelajaran bahasa Indonesia berfungsi pula sebagai sarana untuk membantu peserta didik mengemukakan gagasan dan perasaan, berpartisipasi dalam masyarakat dengan menggunakan bahasa tersebut, dan menemukan serta menggunakan kemampuan analitis dan imajinatif (Depdiknas 2006).

Menurut Schleppegrell (2004), sekolah perlu meningkatkan kesadaran peserta didik mengenai kekuatan pilihan kata dalam penafsiran berbagai makna dan beragam konteks sosial. Apa yang dikemukakan Schleppergrell ini pun relevan dengan tujuan pengajaran bahasa dan sastra Indonesia.

Di sekolah, guru menghadapi peserta didik dengan berbagai latar belakang sosial-budaya. Tantangan guru tidak hanya mengajarkan bahasa Indonesia untuk mengarahkan peningkatan kemampuan berbahasa, tetapi juga membentuk sikap mereka terhadap bahasa Indonesia. Untuk itu diperlukan strategi guru dalam mengajarkan bahasa Indonesia bukan hanya sebagai alat untuk meningkatkan kemampuan kognitif mereka, melainkan juga untuk meningkatkan apresiasi mereka terhadap seni-dalam hal ini adalah kesusastraan.

Berdasarkan Kurikulum Berbasis Kompetensi dan Kurikulum Tingkat Satuan Pendidikan, guru mempunyai keleluasaan untuk menentukan bahan ajar kebahasaan dan kesastraan sesuai dengan kondisi lingkungan sekolah dan kemampuan peserta didik. Namun, sejauh mana keleluasaan guru mengatur bahan ajar kebahasaan ini? Hal apa yang diperlukan oleh guru dalam penentuan bahan ajar? Benarkah harus ada pemisahan yang jelas antara pendidikan bahasa dan sastra di sekolah?

Secara khusus, makalah ini akan menyoroti pengajaran bahasa dan sastra di sekolah dasar dan kaitannya dengan strategi guru menghadapi Kurikulum Tingkat Satuan Pendidikan. Alasan yang mendasari penulis menyoroti pengajaran bahasa dan sastra di sekolah dasar adalah karena tahun-tahun pertama di sekolah dasar merupakan waktu yang sangat penting dalam 
peningkatan keterampilan menggunakan bahasa Indonesia. Karena itu, guru mempunyai peran penting dalam meningkatkan keterampilan ini.

Di dalam makalah ini akan diuraikan secara singkat Kurikulum Berbasis Kompetensi dan Kurikulum Satuan Tingkat Pendidikan, dan hubungan antara perkembangan bahasa dan pengajaran bahasa serta pengajaran sastra. Makalah ini akan ditutup dengan saran bagi guru untuk menyiasati Kurikulum Satuan Tingkat Pendidikan dalam pengajaran bahasa dan sastra Indonesia.

\section{KBK DAN KTSP}

Sampai saat ini, Indonesia masih menghadapi banyak masalah dalam bidang pendidikan. Tilaar (1998) mengungkapkan bahwa paling tidak ada tujuh masalah pokok dalam sistem pendidikan nasional, yaitu menurunnya akhlak dan moral peserta didik, pemerataan kesempatan belajar, masih rendahnya efisiensi internal sistem pendidikan, status kelembagaaan, manajemen pendidikan yang tidak sejalan dengan pembangunan nasional, dan sumber daya yang belum profesional.

Masalah yang pertama, dekadensi moral dan akhlak peserta didik, sedikit banyak banyak dipengaruhi oleh faktor latar belakang para peserta didik. Sementara itu, masalah-masalah lain dalam pendidikan nasional menyangkut institusi pembelajaran.

Dapat dikatakan bahwa sampai saat ini mutu pendidikan di Indonesia memang tidak mengalami peningkatan yang merata. Paling tidak, ada tiga faktor yang menyebabkan hal ini. Yang pertama adalah kurangnya perhatian terhadap proses dalam pendidikan; sebagian besar institusi pendidikan lebih mementingkan hasil pendidikan. Yang kedua adalah sangat kuatnya peran institusi pemerintah dalam kebijakan pendidikan, yang menyebabkan banyak sekolah kehilangan kemandirian, motivasi, dan inisiatif untuk mengembangkan dan memajukan lembaganya. Yang ketiga adalah kurangnya peran serta orang tua peserta didik dalam penyelenggaraan pendidikan.

Faktor-faktor penyebab masalah pendidikan, seperti disebutkan di atas, sudah lama disadari oleh Departemen Pendidikan Nasional. Untuk memperbaiki keadaan ini, pemerintah menyusun kurikulum yang lebih menekankan kemampuan peserta didik dalam belajar, yakni Kurikulum Berbasis Kompetensi (KBK). Selain itu, pemerintah juga melakukan reorientasi penyelenggaraan pendidikan, yaitu dari manajemen peningkatan mutu berbasis pusat menjadi manajemen peningkatan mutu berbasis sekolah.

KBK merupakan sebuah kurikulum yang menekankan pengembangan kemampuan melakukan tugas-tugas dengan standar kinerja tertentu. Depdiknas (2002, seperti dikutip dalam Mulyasa 2006: 42) mengemukakan bahwa KBK memiliki karakteristik sebagai berikut.

1. Menekankan pada ketercapaian kompetensi siswa, baik secara individual maupun secara klasikal.

2. Berorientasi pada hasil belajar dan keberagaman. 
3. Penyampaian dalam pembelajaran menggunakan metode yang bervariasi.

4. Sumbernya bukan hanya guru, tetapi juga sumber belajar lainnya yang memenuhi unsur edukatif.

5. Penilaian menekankan pada proses belajar dan hasil belajar dalam upaya penguasaan atau pencapaian suatu kompetensi.

Walaupun kurikulum ini sudah dicanangkan pemerintah, sejumlah masalah masih tetap bermunculan. Keterbacaan kurikulum ini merupakan kendala yang utama. Masih banyak penyelenggara pendidikan yang masih kurang memahami hakikat kurikulum ini. Selain itu, kewenangan guru untuk menjabarkan kurikulum ini sebagai acuan dalam pembelajaran masih sangat terbatas. Untuk meningkatkan peran guru dalam pelaksanaan kurikulum, pemerintah menyusun Kurikulum Tingkat Satuan Pendidikan (KTSP).

KTSP merupakan upaya untuk menyempurnakan kurikulum agar lebih dekat dengan guru (Mulyasa 2006:9). Dengan KTSP, penyelenggara pendidikan, terutama guru, akan banyak dilibatkan dan diharapkan memiliki tanggung jawab yang memadai. Alwasilah (2006) mengungkapkan sejumlah ciri penting KTSP ini sebagai berikut.

1. KTSP menganut prinsip fleksibilitas; sekolah diberi kebebasan untuk memberi tambahan empat jam per minggu, yang dapat diisi dengan muatan lokal maupun pelajaran wajib.

2. KTSP membutuhkan pemahaman dan keinginan sekolah untuk mengubah kebiasaan lama, yaitu kebergantungan pada birokrat.

3. Guru kreatif dan siswa aktif.

4. KTSP dikembangkan dengan prinsip diversifikasi; sekolah berperan sebagai "makelar" kearifan lokal.

5. Komite sekolah bersama dengan guru mengembangkan kurikulum.

6. KTSP tanggap terhadap iptek da seni, berpusat pada potensi, perkembangan, kebutuhan, dan kepentingan peserta didik dan lingkungan.

7. KTSP beragam dan terpadu; walaupun sekolah diberi otonomi dalam pengembangannya, sekolah tetap mengikuti Ujian Nasional.

Hal penting yang perlu dipertimbangkan adalah sebagai berikut (Mulyasa 2006:20).

1. KTSP dikembangkan sesuai dengan kondisi satuan pendidikan, potensi dan karakteristik daerah, latar sosial budaya masyarakat setempat dan peserta didik.

2. Sekolah dan komite sekolah mengembangkan kurikulum tingkat satuan pendidikan dan silabusnya berdasarkan kerangka dasar kurikulum dan standar kompetensi lulusan, di bawah supervisi dinas pendidikan kabupaten/kota, dan departemen agama yang bertanggung jawab di bidang pendidikan. 
Dapat dikatakan bahwa tujuan penyusunan KTSP sangat mulia, yaitu meningkatkan peran serta penyelenggara pendidikan dan masyarakat-dalam hal ini diwakili oleh Dewan Sekolah-dalam proses belajar mengajar. Namun, sekali lagi, kemampuan "menerjemahkan" dan melaksanakan kurikulum ini menjadi sangat penting. Jika dikaitkan dengan pengajaran bahasa dan sastra Indonesia, pemahaman mengenai hakikat pemerolehan, pemelajaran, dan pengajaran bahasa menjadi sangat penting.

Pemerolehan, Pemelajaran, Pembelajaran Bahasa: Berbicara, Mendengarkan, MembaCA, DAN MenUlis

Istilah pemerolehan bahasa dibedakan dari pemelajaran bahasa. Pemerolehan bahasa dipakai dalam proses penguasaan bahasa pertama, yaitu proses perkembangan yang terjadi pada seorang manusia sejak ia lahir. Pemelajaran bahasa adalah proses mempelajari bahasa, yang dipakai dalam proses belajar bahasa (umumnya bahasa yang dipelajari secara formal di sekolah atau bahasa asing) yang dialami oleh seorang anak atau orang dewasa setelah ia menguasai bahasa pertama (Darmojuwono dan Kushartanti 2005:24). Menurut Oxford (1990), pemerolehan bahasa muncul secara spontan dan secara tidak disengaja. Sementara itu, pemelajaran bahasa dimunculkan secara sadar; pemelajaran dipelajari dengan instruksi formal.

Proses pemerolehan bahasa bukanlah sesuatu yang sederhana. Di dalam pengalaman setiap manusia yang normal, berbahasa adalah proses kognitif yang rumit. Proses ini mensyaratkan kematangan otak dan kematangan alatalat ucap. Ada sejumlah tahap yang terjadi dalam otak manusia sampai ia menghasilkan ujaran. Di dalam hal ini, tingkat kemampuan memahami pada manusia jauh lebih besar daripada kemampuannya untuk memproduksi bahasa. Dengan demikian, kemampuan mereka untuk menghasilkan ujaran terjadi lebih belakangan dibandingkan dengan kemampuan mereka memahami ujaran.

Salah satu fase penting dalam pemerolehan bahasa yang berkaitan erat dengan pembelajaran bahasa adalah fase imitasi. Pada fase imitasi, anak-anak akan meniru orang-orang di sekitarnya untuk berbicara. Dalam fase inilah anak-anak mengasah keterampilan mereka dalam bercerita.

Cerita, mendengarkan cerita, dan bercerita adalah aspek yang sangat penting dalam pemerolehan bahasa. Keakraban anak pada bentukbentuk cerita merupakan nilai penting dalam proses pemerolehan bahasa. Pengalaman anak yang diperoleh dengan mendengarkan cerita dapat memperkaya perbendaharaan kata. Selain itu, anak juga memperoleh pengetahuan mengenai ragam bahasa, dalam hal ini ada ragam formal yang biasanya terdapat dalam bahasa tulis, dan ragam informal dalam bahasa lisan. Keterampilan bercerita, seperti menyampaikan informasi faktual secara jelas, merupakan keterampilan yang tidak diperoleh dengan sendirinya. Keterampilan ini menjadi bagian dari pembelajaran bahasa oleh guru. 
Bercerita menjadi sangat penting dalam proses pemerolehan bahasa karena melalui bercerita anak-anak dapat mengolah kembali semua bentuk pengalaman mereka dalam bahasa. Melatih anak untuk bercerita berarti melatih mereka untuk berani berbicara di depan orang lain. Menurut Wray dan Medwell (1991), dengan bercerita, atau merangkai peristiwa dalam ujaran, anak-anak memperoleh kesempatan mengungkapkan hal yang sudah terjadi, menyampaikan apa yang sedang terjadi, dan meramalkan apa yang akan terjadi.

Dengan bercerita, anak-anak juga belajar menyesuaikan persepsinya dengan persepsi orang lain. Pada saat yang sama, anak-anak lain berlatih untuk menyimak cerita. Keterampilan ini tampaknya mudah, namun dalam pelaksanaannya dapat menjadi sangat sulit untuk dimulai. Di sinilah peran guru untuk mendorong anak agar belajar menghormati orang yang sedang berbicara.

Proses belajar bahasa pada anak di sekolah sangat dipengaruhi oleh pengalaman mereka sebelumnya, yaitu sebelum mereka menginjak bangku sekolah formal. Kesenangan belajar bahasa pada dasarnya berasal dari pengalaman yang menyenangkan. Misalnya, ketika anak diperkenalkan pada bentuk-bentuk tulisan dan gambar. Kesadaran mereka akan hubungan antara sesuatu yang tertulis dengan sesuatu yang diujarkan merupakan langkah awal yang baik untuk memperkenalkan bentuk pengungkapan bahasa yang lain, yaitu membaca dan menulis.

Kesadaran mengenai hubungan antara sesuatu yang tertulis dan sesuatu yang diujarkan mereka dapatkan ketika mereka mengetahui adanya hubungan antara gambar dan cerita dalam buku cerita. Karena itu, sudah sering pula kita mendengar bahwa memperkenalkan anak pada buku-buku cerita bergambar sebelum mereka siap untuk membaca dan menulis adalah hal yang sangat penting.

Belajar membaca dan menulis di sekolah merupakan hal yang tidak dapat dielakkan dalam pelajaran bahasa Indonesia. Pada tingkat-tingkat awal, anak-anak didorong untuk mampu membaca dan menulis kalimatkalimat sederhana. Pada tingkat selanjutnya anak-anak harus memahami penanda-penanda hubungan logis. Hal ini perlu disadari benar oleh guru, karena berpikir logis inilah yang akan menjadi landasan penting dalam pemahaman mata pelajaran yang lain. Seperti halnya bercerita secara logis, menulis secara logis pun merupakan kompetensi dasar yang harus dimiliki oleh pemelajar.

Dapat dikatakan bahwa pembelajaran bahasa pada hakikatnya adalah proses untuk mencapai empat kompetensi komunikatif. Menurut Oxford (1990: 7) keempat kompetensi komunikatif tersebut adalah sebagai berikut.

1. Kompetensi gramatikal, yaitu penguasaan tanda-tanda bahasa, termasuk kosakata, tata bahasa, pelafalan, ejaan, dan pembentukan kata.

2. Kompetensi sosiolinguistis, yaitu kemampuan menggunakan ujaran dalam konteks sosial yang bervariasi, termasuk di dalamnya adalah 
pengetahuan mengenai pertuturan seperti membujuk, meminta maaf, atau menjelaskan.

3. Kompetensi wacana, yaitu kemampuan untuk menggabungkan gagasangagasan untuk mencapai kesatuan dan kepaduan pikiran dalam satuan bahasa di atas kalimat.

4. Kompetensi strategis, yaitu kemampuan menggunakan strategi untuk mengatasi keterbatasan pengetahuan bahasa.

\section{Bersastra: Pengajaran Kreativitas Berbahasa}

Sering kali, pengajaran sastra terabaikan karena ada sejumlah pelajaran lain yang dianggap lebih penting. Padahal, pengajaran sastra sangat penting dalam perkembangan manusia, bukan hanya penting sebagai sesuatu yang "terbaca" melainkan juga sebagai sesuatu yang memotivasi kita untuk berbuat.

Norton (1983), Hucks dkk. (1987), Wray dan Medwell (1991), seperti juga Alwasilah (2006), mengungkapkan pentingnya memasukkan pengajaran sastra di sekolah karena sejumlah alasan sebagai berikut. Karya sastra menjembatani hubungan realita dan fiksi, hal ini mendukung kecenderungan manusia yang menyukai realita dan fiksi. Melalui karya sastra, pembaca belajar dari pengalaman orang lain dalam menghadapi masalah dalam kehidupan. Di dalam sastra terdapat nilai-nilai kehidupan yang tidak diberikan secara preskriptif - harus begini, jangan begitu - tetapi dengan membebaskan pembaca mengambil manfaatnya dari sudut pandang pembaca itu sendiri melalui interpretasi. Melalui karya sastra pula peserta didik ditempatkan sebagai pusat dalam latar pendidikan bahasa, eksplorasi sastra, dan perkembangan pengalaman personal. Keakraban dengan karya sastra, seperti yang telah diungkapkan sebelumnya memperkaya perbendaharaan kata dan penguasaan ragam-ragam bahasa, yang mendukung kemampuan memaknai sesuatu secara kritis dan kemampuan memproduksi narasi.

Di dalam KTSP telah dinyatakan bahwa mata pelajaran Bahasa Indonesia mempunyai tujuan agar peserta didik mempunyai kemampuan sebagai berikut.

1. Berkomunikasi secara efektif dan efisien sesuai dengan etika yang berlaku, baik secara lisan maupun tertulis.

2. Menghargai dan bangga menggunakan bahasa Indonesia sebagai bahasa persatuan dan bahasa negara.

3. Memahami bahasa Indonesia dan menggunakannya dengan tepat dan kreatif untuk berbagai tujuan.

4. Menggunakan bahasa Indonesia untuk meningkatkan kemampuan intelektual, serta kematangan emosional dan sosial.

5. Menikmati dan memanfaatkan karya sastra untuk memperluas wawasan, memperhalus budi pekerti, serta meningkatkan pengetahuan dan kemampuan berbahasa

6. Menghargai dan membanggakan sastra Indonesia sebagai khazanah budaya dan intelektual manusia Indonesia. 
Di dalam KTSP dengan jelas diungkapkan bahwa salah satu tujuan pengajaran bahasa Indonesia adalah agar peserta didik secara kreatif menggunakan bahasa untuk berbagai tujuan. Kreativitas berbahasa dapat dipakai pula untuk mengekspresikan diri. Dalam hal ini, peserta didik bersinggungan dengan sastra.

Sudah seharusnya guru memperkenalkan karya sastra sebagai suatu bentuk seni (yang erat kaitannya dengan kreativitas) berbahasa. Pengajaran sastra ditekankan pada bagaimana mengapresiasikan karya, bukan pada menghafal karya sastra. Dorongan guru kepada peserta didik untuk bercerita, seperti diungkapkan pada bagian sebelumnya, sebaiknya juga dikaitkan dengan pembelajaran sastra. Peserta didik perlu diperkenalkan pada fungsi sastra sebagai alat mengekspresikan diri, baik dalam bentuk cerita, puisi, dan drama (yang mula-mula diperkenalkan sebagai bermain pura-pura).

Menurut Sumardi (2000), agar anak dapat memperoleh kesenangan dan manfaat dalam membaca karya sastra itu, kunci utama yang perlu dipikirkan dalam buku pelajaran adalah menyediakan karya sastra anak yang unggul yang sesuai dengan minat dan kematangan jiwa anak. Untuk memilih karya sastra anak yang unggul, diminati, dan sesuai dengan kematangan jiwa anak, dapat digunakan acuan ilmu-ilmu yang relevan seperti ilmu sastra dan psikologi perkembangan. Huck dkk. (1987) mengungkapkan bahwa ciri esensial karya sastra anak adalah penggunaan pandangan anak dalam menghadirkan cerita atau dunia imajiner. Karena itu pulalah, guru perlu benar memahami dunia ini.

\section{Strategi Guru Bahasa IndONESIa dalam MENYIKapi KTSP}

Menurut Cunningsworth (1995) ada dua dimensi konteks belajar bahasa, yaitu konteks bahasa dan konteks anak. Konteks bahasa antara lain mensyaratkan bahasa yang dipelajari itu harus utuh, tidak lepas-lepas, dan jelas ragamnya. Konteks anak antara lain mensyaratkan bahasa yang dipelajari itu harus sesuai dengan lingkungan, kebutuhan bahasa, kematangan jiwa, dan minat anak. Berdasarkan apa yang dikemukakan oleh Cunningsworth tersebut, pemilihan bahan ajar sudah sepatutnya mempertimbangkan kedua konteks tersebut. Nunan (1995) juga mengungkapkan bahwa bahan atau wacana pembelajaran bahasa sebaiknya dipilih berdasarkan konteks sosial, budaya, kebahasaan, dan kehidupan siswa.

Keleluasaan guru untuk memilih apa yang diajarkan dalam mata pelajaran Bahasa Indonesia sebaiknya dilandasi oleh pertimbangan mengenai apa yang diungkapkan oleh Cunningsworth dan Nunan di atas. Karena pembelajaran bahasa berkaitan dengan pembelajaran budaya, maka sebaiknya guru juga mempertimbangkan aspek-aspek budaya yang ada di Indonesia. Dalam hal ini, kekuatan karya sastra dapat dimanfaatkan.

Yang menjadi pertanyaan adalah: bagaimana mendorong anak untuk menyukai karya sastra dalam proses pemelajaran bahasa? Wray dan Medwell (1991: 56--63) menyarankan sejumlah strategi untuk mendorong anak 
berinteraksi dengan kesusastraan. Strategi itu adalah pilihan (choice) yang diberikan oleh guru kepada peserta didik, kesempatan (opportunity) untuk membaca, suasana (atmosphere) yang dibangun dalam menikmati karya sastra, contoh (model) yang dapat ditiru oleh peserta didik dalam budaya membaca, dan berbagi (sharing) informasi mengenai apa yang sudah dibaca. Strategistrategi ini dapat diterapkan oleh pengelola pendidikan sebagai langkah pelaksanaan KTSP ini sebagai berikut.

Guru dapat memberi kesempatan peserta didik untuk memilih bacaan yang disukainya. Mungkin, pada mulanya bacaan itu bukanlah bacaan yang dinilai baik oleh guru. Namun, dengan memberi kebebasan peserta didik untuk memilih dan menikmati bacaan pilihannya, guru dapat memperkenalkan peran bacaan sebagai sarana untuk memperkaya pengetahuan. Setelah itu, guru dapat meminta peserta didik untuk memilih bacaan yang temanya sudah ditentukan oleh guru.

Peserta didik perlu diberi kesempatan seluas-luasnya untuk membaca secara individual. Misalnya, jika peserta didik datang lebih awal, mereka boleh membaca bacaan yang mereka pilih. Keleluasaan menentukan bahan ajar, seperti tertuang dalam KTSP, sebaiknya juga mempertimbangkan keleluasaan waktu untuk membaca dan mendiskusikan apa yang telah dibaca.

Suasana menyenangkan perlu dibangun di sekolah. Suasana dapat dibedakan menjadi suasana fisik dan suasana sosial. Suasana fisik berkaitan dengan penempatan buku yang rapi dan menarik. Suasana sosial dapat dibangun di kelas dengan menciptakan iklim persaingan sehat dalam membaca buku. Misalnya saja, anak-anak diminta untuk membaca buku yang berhubungan dengan sastra sebanyak-banyak dalam waktu tertentu, dan siapa yang paling banyak membaca akan mendapatkan hadiah.

Tidak dapat dimungkiri bahwa peserta didik berasal dari latar belakang yang beragam. Ada keluarga yang membiasakan anak untuk membaca, ada yang tidak. Guru dapat menunjukkan antusiasmenya dalam kesempatan membaca. Antusiasme guru ini dapat menjadi contoh yang baik bagi peserta didik. Guru juga dapat lebih dahulu membicarakan buku favoritnya, dan menunjukkan bagaimana waktu membaca adalah waktu yang sangat menyenangkan.

Melalui karya sastra, anak juga dapat berbagi pengalaman dan perasaan. Menceritakan pengalaman yang hampir mirip atau sama sekali berbeda berdasarkan buku yang dibaca merupakan kegiatan yang seharusnya menambah minat peserta didik dalam belajar berbahasa. Selain itu mendorong anak untuk menciptakan puisi sebagai bentuk ekspresi pengalaman dan perasaan juga penting. Namun, perlu diingat bahwa setiap anak mempunyai minat yang berbeda mengenai hal ini. Memaksa anak untuk menciptakan suatu bentuk ekspresi bahasa bukanlah tindakan yang bijaksana. 


\section{Beber apa Saran untuk Pengelola Pendidikan}

Seperti telah diungkapkan pada bagian kedua makalah ini, KTSP mempunyai tujuan yang mulia untuk mencerdaskan bangsa dengan meningkatkan peran pengelola sekolah, guru, dan komite sekolah ditingkatkan. Namun, tujuan mulia ini tidak akan tercapai jika pihak-pihak ini tidak menyadari hakikat dan tujuan pembelajaran bahasa. Ada sejumlah saran yang kiranya dapat menjadi pertimbangan bagi pengelola pendidikan.

1. Guru bahasa Indonesia sebagai pelaksana pembelajaran perlu terusmenerus mengembangkan diri, memperkaya ilmu pengetahuan. Karena pembelajaran bahasa pada hakikatnya adalah pembelajaran budaya, maka guru perlu memahami budaya peserta didik, dengan tidak melupakan tujuan pengajaran, yang salah satunya adalah menghargai dan membanggakan sastra Indonesia sebagai khazanah budaya dan intelektual manusia Indonesia.

2. Pengelola sekolah perlu meningkatkan pemanfaatan perpustakaan. Buku-buku bacaan di perpustakaan harus dapat dimanfaatkan untuk kepentingan belajar dan mengajar. Guru sebaiknya merancang waktu yang cukup banyak untuk kunjungan ke perpustakaan dan waktu untuk mendiskusikan bacaan, baik secara lisan maupun secara tertulis.

3. Seyogianya, guru bahasa Indonesia bukan saja mempunyai wawasan ilmu linguistik dan pengajaran bahasa, namun juga mempunyai wawasan yang luas mengenai kesusastraan Indonesia, khususnya sastra anak dan wawasan mengenai psikologi anak.

4. Guru bahasa Indonesia perlu terus-menerus berkoordinasi dengan guru mata pelajaran yang lain, sehingga pengembangan keterampilan berbicara, menyimak, membaca, dan menulis tidak hanya terjadi di dalam kelas Bahasa Indonesia, melainkan juga di kelas-kelas yang lain.

5. Peran guru tidak lagi menjadi "penceramah", melainkan menjadi fasilitator. Dengan cara ini, peserta didik akan terus-menerus dipacu untuk berusaha mencari informasi secara aktif.

6. Sejalan dengan saran nomor 5 di atas, peserta didik perlu terus didorong untuk berani bertanya, mengungkapkan pendapat, dan mampu menjadi pendengar yang baik ketika orang lain berbicara. Salah satu cara untuk mengukur kemampuan menyimak adalah dengan meminta peserta didik untuk menceritakan kembali apa yang telah didengarnya ketika orang lain berbicara.

7. Komite sekolah perlu dilibatkan dalam kegiatan belajar-mengajar. KTSP sudah menyarankan hal ini, namun dalam pelaksanaannya, banyak sekolah yang belum memberdayakan komite sekolah. Untuk itu diperlukan koordinasi dan komunikasi yang baik antara komite sekolah dengan pengelola sekolah. Komite sekolah, yang anggotanya adalah orang tua peserta didik, perlu menyadari bahwa prestasi hendaknya bukan hanya diukur dari prestasi nilai, tetapi juga prestasi proses. Karena itu, hendaknya pandangan ini perlu disadari benar oleh 
Komite Sekolah yang menjadi jembatan antara kepala sekolah, guru, dan orang tua.

\section{DAFTAR ACUAN}

Alwasilah, A. Chaedar. 2006. "Kurikulum Berbasis Sastra." Makalah dalam Seminar Nasional Kondisi Bahasa Indonesia Masa Kini. Jakarta, 16 Desember 2006.

Cunningsworth, Allan. 1995. Choosing Your Coursebook. Oxford: Heinemann.

Darmojuwono, Setiawati dan Kushartanti.2005. "Aspek Kognitif Bahasa” dalam Kushartanti, Untung Yuwono, dan Multamia RMT Lauder (peny.) PesonaBahasa: Langkah Awal Memahami Linguistik. Jakarta: Gramedia PustakaUtama.

Huck, Charlotte S., Susan Hepler, dan Janet Hickman. 1987. Children's Literature. New York: Holt, Rinehart and Winston, Inc.

Kushartanti. 2005. "Adek Bayi Di-pake-sepatu-in Dulu" dalam Totok Suhardiyanto, Untung Yuwono, dan Syahrial (peny.), Dari Kampus ke Kamus: 65 Tahun Program Studi Indonesia. Depok: Program Studi Indonesia FIB-UI, hlm. 69--82.

Mulyasa, E. 2006. Kurikulum Tingkat Satuan Pendidikan: Sebuah Panduan Praktis. Bandung: PT Remaja Rosdakarya.

Norton, Donna E. 1983. Through the Eyes of a Child: An Introduction to Children's Literature. Ohio: Charles E. Merril Publishing Co.

Nunan, David . 1993. Introducing Discourse Analysis. London: Penguin.

----. 1995. Language Teaching Methodology: A Textbook for Teachers. New York: Phoenix.

Oxford, Rebecca L. 1990. Language Learning Strategies: What Every Teacher Should Know. New York: Newburry House Publishers.

Schleppegrell, Mary J. 2004. The Language of Schooling: A Functional Linguistics Perspective. Mahwah, New Jersey, London: Lawrence Erlbaum Associates.

Sumardi. 2000. Panduan Penelitian, Pemilihan, Penggunaan, dan Penyusunan: BukuPelajaran Bahasa Indonesia SD sebagai Sarana Pengembangan Kepribadian,Penalaran, Kreativitas, dan Keterampilan Berkomunikasi Anak. Jakarta: Grasindo.

Tilaar, HAR. 1998. Manajemen Pendidikan Nasional: Kajian Pendidikan Masa Depan. Bandung: Remaja Rosdakarya.

Wray, David, dan Jane Medwell. 1991. Literacy and Language in the Primary Years. London dan New York: Routledge. 